\title{
PAPERS TO APPEAR IN ARCTIC
}

Laforest, B.J., Hébert, J.S., Obbard, M.E., and Thiemann, G.W. Traditional Ecological Knowledge of Polar Bears in the Northern Eeyou Marine Region, Québec, Canada.

Keenan, E., Fanning, L.M., and Milley, C. Mobilizing Inuit Qaujimajatuqangit in Narwhal Management through Community Empowerment: A Case Study in Naujaat, Nunavut.

Damman, D.O., Eicken, H., Mahoney, A.R., Meyer, F.J., and Betcher, S. Assessing Sea Ice Trafficability in a Changing Arctic.

Tomaselli, M., Gerlach, S.C., Kutz, S.J., Checkley, S.L., and the Community of Iqaluktutiaq. Iqaluktutiaq Voices: Local Perspectives about the Importance of Muskoxen, Contemporary and Traditional Use and Practices. 